Bayero Journal of Pure and Applied Sciences, 4(2): 121 - 127

Received: November, 2010

Accepted: August, 2011

ISSN $2006-6996$

\title{
BIOLOGICAL ASSESSMENT OF WATER QUALITY: A STUDY OF CHALLAWA RIVER WATER KANO, NIGERIA
}

\author{
*Suleiman, $\mathrm{K}^{1}{ }^{1}$ and Abdullahi, I.L. ${ }^{2}$ \\ ${ }^{* 1}$ Department of Biological Sciences College of Arts, Science and Remedial Studies Kano. \\ ${ }^{2}$ Department of Biological Sciences, Bayero University Kano. \\ *Correspondence author: kbsuleiman@yahoo.com
}

\begin{abstract}
This study was carried out to survey the biotic community of Challawa river water in Kano, Nigeria, using Biological Monitoring Working Party Score (BMWP) and Average Score Per Taxa (ASPT) assessment tools to evaluate the water quality in the field. Using standardized sampling technique insects, insects' larvae, benthic invertebrates, fresh water vivalve, prosobranch and Pulmonate Gastropods of the river were collected, indentified using identifications keys and BMWP score table. BMWP performances and ASPT values obtained were recorded for each selected site $A, B, C$ and $D$ during sampling period between February to October. The results revealed that Site A, close to water treatment plant, had a total of 63 species count, the total performance of 53 BMWP score; was (high)10 in March but fell sharply to 2(low) in May and the ASPT value obtained was 0.84 as the less sensitive species dominate the sample size and indicating water of B-class quality. Site B, the water intake Station of the Challawa water works had 37 species count, 44 BMWP performances and 1.19 ASPT value assessed A-class. Site C, industrial effluent discharge point, had 51 counts, 28 BMWP performances with 0.55 ASPT value assessed D-class. Site D, the confluent point between River Challawa and River Kano had 67count, 58 BMWP performances and 0.87 ASPT value assessed $B$-class. The implications of the findings were discussed and recommendations for possible abatement of the situation made.

Key words: Macro invertebrates, quality, assessment, Challawa River, ASPT, BMWP
\end{abstract}

\section{INTRODUCTION}

Water problems exist around the world with respect to the: quantity, quality, source for new supplies, distribution and allocation. The inevitable consequence of this is the demand for water in Kano has greatly increased in recent times, natural state of challawa river water resources are progressively deteriorating in quality. Challawa River provides more than two Million liters of raw water daily to the Kano water works for processing (Nasiru, 2008). Rivers and lakes account for a very small proportion of the earth's freshwater, about $0.33 \%$ and $0.40 \%$ respectively (Lloyd 1992). Challawa River in Kano State provides portable water for a wide range of domestic purposes and the river is prone to contamination or pollution from industrial, agricultural and domestic sources. These wastes which are of various types and composition are capable of changing the natural state (quality) of the river water. Most importantly, the pollution in the water can affect the occurrence, composition as well as the distribution of many aquatic species, depending on their levels of tolerance and adaptability. In some densely populated countries the quantity and conditions of most rivers have changed (Anolda et. al., 1999). Surface waters were used as systems for quality assessment (Todd, 1970). Ahmed and Tanko (1994) comment on the change in the flow regime of Challawa River and remarked that effluent flowing into the river from main industrial areas (Challawa and Sharada) is Likely to cause pollution. Ibrahim et. al.,
(2002) showed varying levels of metallic ions in the algae (Microspora amoena) found inhabiting the sedimentation tank of Challawa water works tanks.

Recently, techniques and scope in surface water quality assessment were improved (Anolda et. al., 1999). Chapman (1996) advised that the selection of water quality variables should be dictated by techniques and models available. Several biological indices have been developed to assess water quality in the field (Depauw and Vanhooren, 1983; Washington, 1984; Hellawell, 1986 and Metcalfe, 1989). Mason, (1996) reviewed the ecology and responses of many aquatic organisms in water quality assessment. Organisms reported to be successful in the water quality assessment include fishes, molluscs and some macro invertebrates (Allison, 1987), in running waters, macro invertebrates are prefer in water quality assessment studies (Metcalfe, 1989). Diversity and distribution of macro invertebrates in Challawa River have been reviewed (Sani, 2003).

This study was undertaken to survey the biotic community of the Challawa river water ecosystem, biweekly and seasonally (Marsh, 1982) and indentify the loci or point along the water course where diversity and abundance is poor (Washington, 1984; Metcalfe, 1986). Using biotic indices; Biological Monitoring Working Party Score (BMWP) and Average Score Per Taxa (ASPT) to evaluate the condition (quality) of the river (Zamora-Munoz, 1985). 


\section{MATERIALS AND METHODS \\ Study area}

Challawa River Figure 1 is located on the southern part of Kano between the latitude of $12^{\circ} \mathrm{N}$ and $12^{0}$ $02 \square \mathrm{N}$ and on longitude of $8.5^{\circ} \mathrm{E}$ and $8.7^{\circ} \mathrm{E}$. It has a confluence with river Kano at Tamburawa and is about Fifty kilometers (50) in length. It flows due south west. It is about 500 meters above the sea levels (Olofin, 1985).

The climates of the area are tropical wet and dry with a mean annual rainfall of $600 \mathrm{~mm}$ to $1000 \mathrm{~mm}$ (Olofin, 1987). The mean annual and monthly temperatures are $26^{\circ} \mathrm{C}$ and $21^{\circ} \mathrm{C}$ respectively, although relatively high during the wet season and evaporation is never in excess of rainfall Olofin, (1987). Four sampling points were chosen and designated $A, B, C$ and $D$ along the stretch of the river. Site $A$ is close to the water treatment plant. Site B is the water intake station adjacent to the new water works which draws water for processing. This site is boarded by agricultural activities. Site $\mathrm{C}$ is the point where industrial effluent flows directly into the river water. Lastly, Site D is the confluence point with river Kano, a place called Tamburawa village.

\section{Sample collection}

Challawa River was studied for 9 month from February to October during which samples were collected fortnightly through dry and wet season from each the selected sites.
Average
Score
Summation of BMWP Score

\section{Total number of species (macroinvertebrates)from $\frac{\text { wate }}{\text { site }}$}

Using a wooden handle sweeping net, insects' community of the river sampled at different sampling points. Insects' larvae were also sampled by dipping brown bottle and hand picking around between 8:00am - 9:00am (Hellawell, 1986). The river bed was scooped for benthic invertebrates using improvised Ekman grab as described by Maitland (1978). The mud samples were then placed on a white opaque plastic tray of about $50 \mathrm{~cm}$ in diameter and were thoroughly searched for mud inhabiting invertebrates their special identifiable features were observed and recorded for each site following Helen (1963).

Different fresh water bivalve, Prosobranch and Pulmunate Gastropods were collected from selected points by hand picking. The species of invertebrate collected were taken to the laboratory for identification. The identification was carried out using the identification keys as described by Huchinson (1967) and Cole, (1979).

\section{Sample Analysis}

The analytical procedures were that, identified sampled species from each site were assigned with the scores following Biological Monitoring Working Party (BMWP), sum of which was divided by the site total number of taxa to produce the Average Score Per Taxa (ASPT) values (quality class) for each site were obtained and recorded following Write et. al., (1993) evaluation technique below:

$$
\text { Taxa (ASPT) }
$$

The results obtained and were compared with Write et. al., (1993), findings in biological quality of rivers.

\section{RESULTS AND DISCUSSION}

Table 1 present the Biological Monitoring Working Party (BMWP) Score table. The sampled species common names, families they belong to and the scores for their presence in the sample were presented in the Table 2, the identification is to the family level, and each family is given a score between 1 and 10 according to the presence or absence of indicator groups and or indicator species (Mason, 1990). The global diversity has lead to the adaptation and modification of several standard biological methods for use with enormous range of organisms (Friedrich, et. al., 1984). The BMWP table scores identified families of macro invertebrates sample from rivers independent of time, season or region in quality assessment studies and have been standardized by the International Organization for Standardization (ISO - BMWP 1979).

Data on biotic communities of the Challawa River from the selected sites $A, B, C$ and $D$ between the months of February to October were presented (Table 2). About 15 different families of macro invertebrate species were identified from Challawa river. The numbers, families and Biological Monitoring Working
Party Score (BMWP) (Table 1) for each taxa were recorded for each site bi-weekly through dry and wet sampling seasons (Zamora - Munoz et. al., 1995). Based on the Biological Working party Score (BMWP), Site $D$ had more species with a score of 10 (Table 6) as the sample is dominated by those taxa least tolerant, such as families of mayflies in February, river bug in May and July. This could be due to the possible absence of perceived contaminants or pollutants. Site A had high BMWP performance in the month of March and April. However, the biotic assemblage reduced sharply in the subsequent month of May (Table 3). Site B had high performance in the month of April, July, August and September, while low performance was observed in February and October (Table 4). Site $D$ had the high BMWP performance owing to the role of the sampled biotic community in the BMWP scale. The number of biotic communities identified from the river water markedly increased in June. Sample from site $C$ however, consist of only few tolerant species (Table 5). Thus rated low on BMWP scale, July, the biotic the biotic assemblage was higher at the site $C$, other sites had few representation, thus, low performance on BMWP scale. 
The lower performance could be due to rains and faunal community at the time of sampling appears to be largely washed away and also could be due to change in quality condition of the water at the site which receives domestic and industrial wastes waters. Benthic chironomids colonized site C and D thus dominate the sample in September. During the month communities with high BMWP ranking were in samples from site $A$ and $D$. The BMWP performance recovered in site $A$ in October perhaps due to colonization by last tolerant species stoneflies which have prominent role in BMWP owing to their great sensitivity to quality condition of a river water. Site D had least BMWP performance in September while high performance was recorded in February, May and July respectively (Table 6).

Table 1: The Biological Monitoring Working Party Score (BMWP)

\begin{tabular}{|c|c|c|}
\hline Common Name & Families & Scores \\
\hline \multirow[t]{2}{*}{ Mayflies } & Siphlonuridae, Heptageniidae, Leptophlebiidae & \\
\hline & Ephemerellidae, Potamanthidae, Ephemeridae & \\
\hline \multirow[t]{2}{*}{ Stoneflies } & Taenioptrygidae, Leuctridae, Capniidae, & \\
\hline & Perlodidae, Perlidae, Chloroperlidae & 10 \\
\hline River Bug & Aphelocheidae, & \\
\hline Caddisflies & Phryganeidae, Molannidae, Beraidae, & \\
\hline & Odontoceridae, Leptoceridae, Goeridae, & \\
\hline & Sericostomatidae & \\
\hline Crayfish & Astacidae & \\
\hline Dragonflies & $\begin{array}{l}\text { Lestidae, Agriidae, Gomphidae, Cordulegasteridae, Aeshnidae, Corduliidae, } \\
\text { Libellulidae }\end{array}$ & 8 \\
\hline Caddisflies & Psychomyidae, Philoptamiidae & \\
\hline Mayflies & Caenidae & \\
\hline Stoneflies & Nemouridae & 7 \\
\hline Caddisflies & Rhyacophilidae, Polycentropidae, Limnephilidae & \\
\hline Snails & Neritidae, Viviparidae, Ancylidae & \\
\hline Caddisflies & Hydroptilidae & \\
\hline Mussels & Unionidae & \\
\hline Shrimps & Corophiidae, Gammaridae & 6 \\
\hline Dragonflies & Platycnemididae, Coenagriidae & \\
\hline Water Bugs & $\begin{array}{l}\text { Mesoveliidae, Hydrometridae, Gerridae, Nepidae, Naucoridae, Notonectidae, } \\
\text { Pleidae, Corixidae }\end{array}$ & \\
\hline Water Beetles & $\begin{array}{l}\text { Haliplidae, Hygrobiidae, Dystiscidae, Gyrinidae, Hydrophilidae, Clambidae, } \\
\text { Helodidae, Dryopidae, Elminthidae, Chrysomelidae, Curculionidae }\end{array}$ & \\
\hline Caddisflies & Hydropsychidae & \\
\hline Craneflies & Tipulidae & 5 \\
\hline Blackflies & Simuliidae & \\
\hline Flatworms & Planariidae, Dendrocoelidae & \\
\hline Mayflies & Betidae & \\
\hline Alderflies & Sialidae & 4 \\
\hline Leeches & Piscicolidae & \\
\hline Snails & Valvatidae, Hydrobiidae, Lymnaeidae, Physidae, Planorbidae & \\
\hline Cockles & Sphaeriidae & \\
\hline Leeches & Glossiphoniidae, Hirudidae, Erpobdellidae & 3 \\
\hline Hoglouse & Asellidae & \\
\hline Midges & Chironomidae & 2 \\
\hline Worms & Oligochaeta (whole class) & 1 \\
\hline
\end{tabular}

Source: Mason (1998); WMO (1988) 
Bajopas Volume 4 Number 2 December, 2011

Table 2: Biological scores allocated to groups of macro invertebrates collected from Challawa River

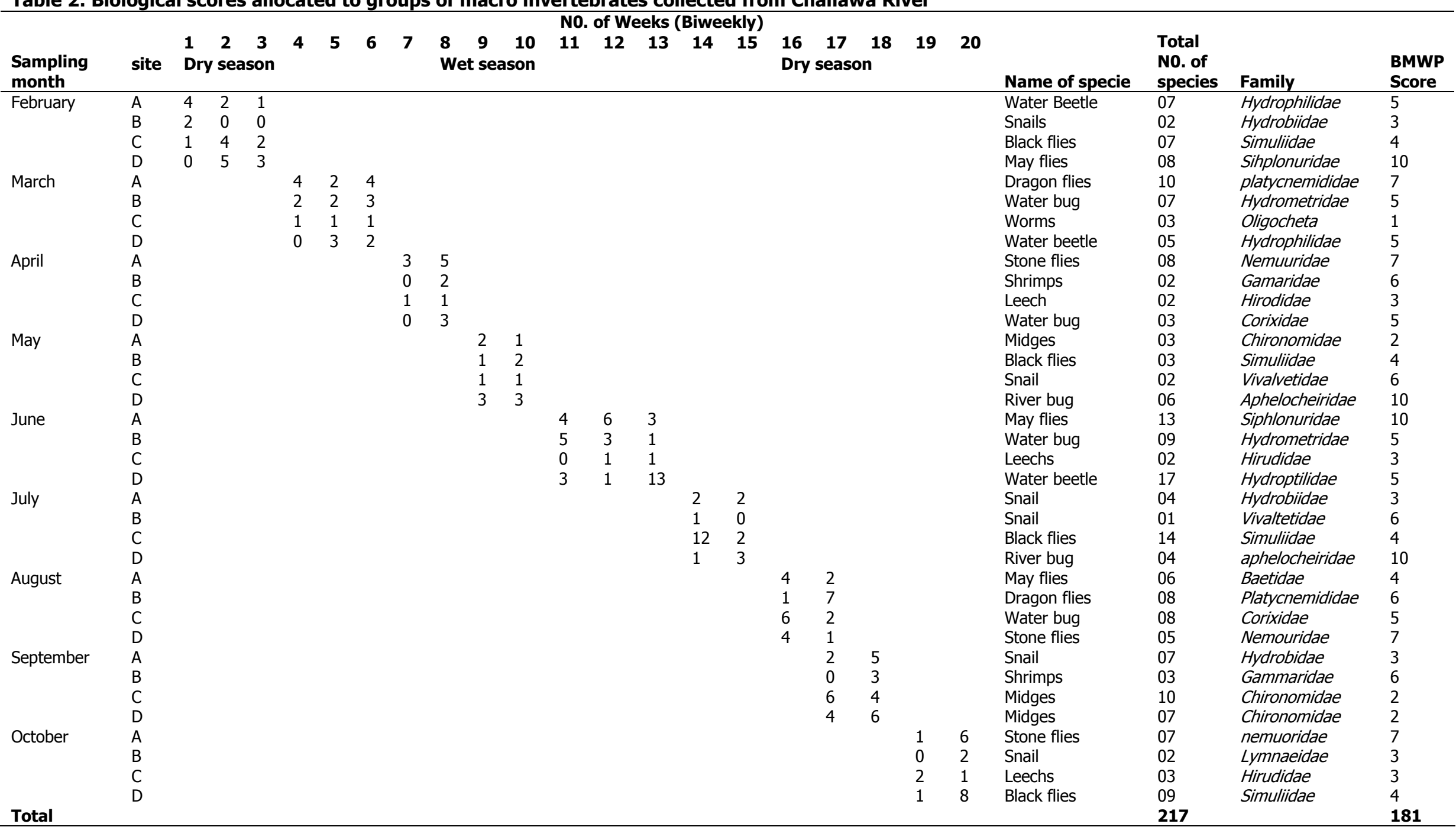


Bajopas Volume 4 Number 2 December, 2011

Table 3: Site A group Biological Scores (BMWP) and Average Score Per Taxa (ASPT) values obtained

\begin{tabular}{llllll}
\hline & $\begin{array}{l}\text { Specie } \\
\text { sampled }\end{array}$ & $\begin{array}{l}\text { Total NO. of } \\
\text { specie }\end{array}$ & Family & BMWP value & $\begin{array}{l}\text { ASPT } \\
\text { obtained }\end{array}$ \\
\hline February & Water beetle & 7 & Hydphalidae & 5 & 0.71 \\
March & May flies & 8 & Siphlonuridae & 10 & 1.25 \\
April & Stone flies & 8 & Nemouridae & 7 & 0.86 \\
May & Midges & 3 & Chironnomidae & 2 & 0.67 \\
June & May flies & 13 & Siphlonuridae & 10 & 0.77 \\
July & Snail & 4 & Vivaltilidae & 5 & 1.25 \\
August & May flies & 6 & Baetidae & 4 & 0.67 \\
September & Snail & 7 & Hydrobidae & 3 & 0.43 \\
October & Stone flies & 7 & Nemouridae & 7 & 1.00 \\
Total & - & $\mathbf{6 3}$ & - & $\mathbf{5 3}$ & $\mathbf{0 . 8 4}$ \\
\hline
\end{tabular}

Table 4: Site B group Biological Scores (BMWP) and Average Score Per Taxa (ASPT) values obtained

\begin{tabular}{llllll}
\hline $\begin{array}{l}\text { Sampling } \\
\text { period }\end{array}$ & $\begin{array}{l}\text { Specie } \\
\text { sampled }\end{array}$ & $\begin{array}{l}\text { Total N0. of } \\
\text { specie }\end{array}$ & Family & BMWP value & $\begin{array}{l}\text { ASPT } \\
\text { obtained }\end{array}$ \\
\hline February & Snail & 2 & Hydroblidae & 3 & 0.67 \\
March & Water bug & 7 & Hydrometridae & 5 & 0.71 \\
April & Shrimps & 2 & Gammaridae & 6 & 3.00 \\
May & Black flies & 3 & Simuliidae & 4 & 1.33 \\
June & Water bug & 9 & Hydrometridae & 5 & 0.56 \\
July & Snail & 1 & Vivalvetidae & 6 & 6.00 \\
August & Dragon fly & 8 & Platycnemididae & 6 & 0.75 \\
September & Shrimps & 3 & Gammaridae & 6 & 2.00 \\
October & Snail & 2 & Lymnadeidae & 3 & 1.50 \\
Total & - & $\mathbf{3 7}$ & - & $\mathbf{4 4}$ & $\mathbf{1 . 1 9}$ \\
\hline
\end{tabular}

Table 5: Site C group Biological Scores (BMWP) and Average Score Per Taxa (ASPT) values obtained

\begin{tabular}{llllll}
\hline $\begin{array}{l}\text { Sampling } \\
\text { period }\end{array}$ & $\begin{array}{l}\text { Specie } \\
\text { sampled }\end{array}$ & $\begin{array}{l}\text { Total N0. of } \\
\text { specie }\end{array}$ & Family & BMWP value & $\begin{array}{l}\text { ASPT } \\
\text { obtained }\end{array}$ \\
\hline February & Black flies & 7 & Simulidae & 4 & 1.75 \\
March & Worms & 3 & Oligochata & 1 & 0.33 \\
April & Leeches & 2 & Leechs & 3 & 1.50 \\
May & Snail & 2 & Vivalvetidae & 6 & 3.00 \\
June & Leeches & 2 & Hirudidae & 3 & 1.50 \\
July & Black flies & 14 & Simulidae & 4 & 0.29 \\
August & Water bug & 8 & Corixidae & 5 & 0.63 \\
September & Midges & 10 & Chironomidae & 2 & 0.20 \\
October & Leeches & 3 & Hirudidae & 3 & 1.00 \\
Total & - & $\mathbf{5 1}$ & - & $\mathbf{2 8}$ & $\mathbf{0 . 5 5}$ \\
\hline
\end{tabular}

Table 6: Site D group Biological Scores (BMWP) and Average Score Per Taxa (ASPT) values obtained

\begin{tabular}{llllll}
\hline $\begin{array}{l}\text { Sampling } \\
\text { period }\end{array}$ & $\begin{array}{l}\text { Specie } \\
\text { sampled }\end{array}$ & $\begin{array}{l}\text { Total NO. of } \\
\text { specie }\end{array}$ & Family & BMWP value & $\begin{array}{l}\text { ASPT } \\
\text { obtained }\end{array}$ \\
\hline February & May flies & 8 & Siphlonuridae & 10 & 1.25 \\
March & Water beetles & 5 & Hydrophilidae & 5 & 1.00 \\
April & Water bug & 3 & Corixidae & 5 & 1.67 \\
May & River bug & 6 & Aphelocheiridae & 10 & 1.67 \\
June & Water beetles & 17 & Hydroptilidae & 5 & 0.29 \\
July & River bug & 4 & Aphelocheiridae & 10 & 2.50 \\
August & Stine fly & 5 & nemouridae & 7 & 1.40 \\
September & Midges & 10 & Chironomidae & 2 & 0.20 \\
October & Black flies & 9 & Simulidae & 4 & 0.44 \\
Total & - & $\mathbf{6 7}$ & - & $\mathbf{5 8}$ & $\mathbf{0 . 8 7}$ \\
\hline
\end{tabular}


On the basis of Biological Monitoring Working Party Score (BMWP) and Average Score Per Taxa (ASPT) criteria, the Challawa River water particularly site B, the water intake point (Figure 1) of the state water works is clean, safe and conducive for the survival and flourishing of aquatic communities (Table 7). The water is classified A, meaning high amenity value. It can be abstracted and treated for domestic use such as drinking, washing and industrial processing. Fishing can be practice in such waters (Ennos and Bailey, 1995). Site $C$ along the water course had the lowest
ASPT. Though, characterized by highly tolerant species, but showed poor performance indicating not qualitative enough and therefore rated bad. It would require intensive treatment toke it ma more useful. The contamination by effluents discharged from industries in the area. However, site $A$ and $D$ showed better performance on both BMWP and ASPT scales (Table 7). The water at these sites was classified as good and has high amenity value, thus suitable for abstraction and other uses.

Table 7: Results of Biological quality assessment of Challawa river water sampling points (A, B, C and D) as compared with Wright et al. (1993), Biological quality assessment of River.

\begin{tabular}{|c|c|c|c|c|c|c|c|c|c|c|}
\hline \multirow[b]{2}{*}{$\mathbf{S} / \mathbf{N}$} & \multirow[b]{2}{*}{ Site } & \multirow[b]{2}{*}{$\begin{array}{l}\text { Tot. NO. } \\
\text { of } \\
\text { species } \\
\text { counted }\end{array}$} & \multirow[b]{2}{*}{$\begin{array}{l}\text { BMWP } \\
\text { total } \\
\text { score }\end{array}$} & \multirow[b]{2}{*}{ ASPT } & \multirow[b]{2}{*}{$\begin{array}{l}\text { Water } \\
\text { quality } \\
\text { Classify. }\end{array}$} & \multirow[b]{2}{*}{ Remark } & \multicolumn{3}{|c|}{ Wright et. al., (1993) table } & \multirow[b]{2}{*}{ Remak } \\
\hline & & & & & & & site & ASPT & $\begin{array}{l}\text { Biological } \\
\text { class }\end{array}$ & \\
\hline 1 & A & 63 & 53 & 0.84 & B & Good & A & $\geq 0.89$ & $\mathbf{A}$ & $\begin{array}{l}\text { Very } \\
\text { good }\end{array}$ \\
\hline 2 & B & 37 & 44 & 1.19 & $A$ & $\begin{array}{l}\text { Very } \\
\text { good }\end{array}$ & B & $\begin{array}{l}0.77- \\
0.88\end{array}$ & B & Good \\
\hline 3 & $\mathrm{C}$ & 51 & 28 & 0.55 & $\mathrm{D}$ & Bad & C & $\begin{array}{l}0.66- \\
0.76\end{array}$ & C & Fair \\
\hline 4 & $\mathrm{D}$ & 67 & 58 & 0.87 & $\mathrm{~B}$ & Good & D & $<0.66$ & D & Bad \\
\hline
\end{tabular}

Macro invertebrates in the Challawa River were examined and water qualities in relation to their presence in chosen sites were assessed using BMWP and ASPT assessment indices. From the analysis of the results, the biological condition of site $B$ (the state water works intake) is in satisfactory condition because of the position occupied by the sampled aquatic organisms in BMWP ranking. Therefore, the condition of water at site $B$ is normal with a good quality requirement. The 1.19 ASPT, as compared with obtained value of $(\geq 0.89)$ Write et. al., (1993) in similar quality assessment of some rivers based on sampling at three seasons guided the technique application in the study. Similar biological analyses at site $C$ revealed a poor quality condition. Sampled aquatic macro invertebrates had poor performance in BMWP with 28 total species count and 0.55 ASPT value obtained which is in consonance with the value $\square 0.66$ (Table 7). This is due to waste from domestic and industrial sources in the area. Wilhm and Dorris (1968), after examining diversity in a range of polluted streams, concluded values less than 1 indicated heavily polluted conditions. Mason (1977) examined the diversity of monthly samples of macro invertebrates collected from a hypertrophic and eutrophic site of a lake; the diversity he found was generally lower at the hypertrophic site. The frequent sampling at two weeks interval was carried out, the appearance of seasonally abundant species could result in the misinterpretations of water quality conditions if infrequent (Hughes, 1978). Pinder, et. al., (1987) was found to produce BMWP and ASPT values which were independent of the time of year of sampling and size of sample. Mason, (1977) concluded that a number of species alone gave a more consistent indication of quality conditions of a river.

\section{CONCLUSIONS AND RECOMMENDATIONS}

The biodiversity at site $\mathrm{C}$ is poor and this indicates the extent of pollutions in the river at this site, where wastes are discharge into the river. Generally, Challawa River was of good quality and wastes waters discharge into had apparently little effect on the general condition of the river.

It is therefore recommended that the source of pollutants of the river should regularly monitor by the relevant authorities, in particular the state Ministry of Environment (Pollution Control unit). Detailed research should be carried out to further test the toxic effect of contaminants in fishes and other aquatic organisms in the river. Biological indices; Average Score Per Taxa (ASPT) and Biological Monitoring Working Party Score (BMWP) are effective tools in assessing the condition of a river ecosystem, therefore should be adapted for use by relevant authorities in charge of pollution control. Biotic community in the Challawa River should be regularly monitored as indicators of condition of the river water as complementary to routine chemical quality control. The authorities abstracting challwa River water for public water supply should be equipped with modern chemical pollutants detecting devices and competent personnel to reduce public health risk. 


\section{REFERENCES}

Ahmed, K. and Tanko, A.I. (1994). Stream water quality and pollution Hazard in the river Hadejia, Kano region. paper presented at the $2^{\text {nd }}$ National Hydrology Symposium Organized by the National Committee on UNISCO-IHP. National Institute of Water resource, Kaduna, Nov. 1994

Alison, I.B. (1987). Freshwater ecology. $1^{\text {st }}$ ed. Heinemann Educational Books. London, UK, pp 1-85.

Anolda, C., Dmitry, Z. and Luitauras, S. (1999). Water quality Control, monitoring and wastewater treatments. Journal of Human Environ. Vol. 30. pp295-306. Lithuana, USA.

Chapman, D. (1996). Water quality assessment: $A$ guide to the use of biota, sediments and Water in environmental monitoring. Second ed. Chapman and Hall, London, UK.

Cole, G.A. (1979): Textbook of Limnology. $2^{\text {nd }}$ ed. C.V. Mosby Company. St. Louis Toronto, Canada.

Depanw, N. and Vanhooren, G. (1983). Method for biological quality assessment of water courses in Belgium. Hydrobiologia. 100, pp $153-168$

Ennos A.R. and Bailey, S.E.R. (1995). Problem solving in Environmental Biology. $1^{\text {st }}$ Ed. Longman Scientific and Technical Group. Longman Group UK.

Friedrich, G. and Muller, D. (1984). Rhine. In Whitton, B.A. (edtn.) Ecology of European rivers, pp. 265 - 315. Blackwell, Oxford.

Helen, M. (1963): Animal Life in Fresh Water. A guide to Freshwater Invertebrates. Published By Chapman and Hall, Ltd, London.

Hutchinson, G.E. (1967). A treatiese on limnology. John Wiley and Sons, Inc, USA. pp 223 229.

ISO-BMWP (1979). Assessment of Biological Quality of Rivers by a Macroinvertebrate Score. ISO/TC147/SCS5/WG6/N5,Internationl Organisation for Standardization, Geneva.

Ibrahim, S., Abdullahi, I. L. and Audu, A.A. (2002): Presence of Toxic Algal Species M. amoena at Challawa Water Works in Kano, Nigeria.

Llyod, R. (1992). Pollution and Freshwater Fish. $1^{\text {st }}$ ed. Fishing News Books, London. pp3-10.

Maitland, P.S. (1978): Biology of freshwaters. Blackie and Sons, Ltd, Glasgow.

Marsh, A.W. (1982): Guidelines for evaluating water quality related 62 crops growth. Irrigation Assist. 1982 Annual Technical Conference. Proceedings silver spring Maryland. Pp. 67 77.
Mason, C.F. (1977): The performance of diversity index in describing the zoobenthos of two lakes. J. Appl. Ecol. 14: pp 363 - 367

Mason, C.F. (1989): The causes and consequences of surface water acidification. In: Moris, R., Taylor, E.W., Brown, D.J.A. and Brown, J.A. (eds): Acid toxicity and aquatic invertebrates. Cambridge University Press. Pp. 1-12.

Mason, C.F. (1990): Biological Aspects of Freshwater Pollution. In: Harrison, R.M. (ed) Pollutions: causes, effect and control. Royal Society of Chemistry, London. Pp. $99-125$.

Mason, C.F. (1996). Biology of freshwater pollution. $3^{\text {rd }}$ edition. Department of Biol. And Chemical Sciences. Univ. of Essex Longman Group UK.

Metcalfe. J. L. (1989). Biology of freshwater quality assessment of running water based macroinvertebrates communities. History and present status in Europe. Environ. Pollution, Co. $101-139$

Nasiru, A.Y. (2008): General Manager, Greater Kano Water Works (GMKWS). Personal Contact.

Olofin, E.A. (1987): Some aspects of physical geography of the Kano region and related human responses. Departmental Lecture Series. Bayero University, Kano.

Olofin. E.A. (1985): Human resources to the natural environment in Kano region. $2^{\text {nd }}$ inter Confr. History of Kano. Proceedings $16^{\text {th }}-20^{\text {th }}$ Sept. 1985.

Pinder, L.C.V. and Farr, I.S. (1987): Biological Surveillance of water quality. Arch. Hydrobiol. 109:619 - 637.

Sani, I. (2003). A survey of some aspect of biodiversity and physic-chemical character of Challawa River Water in Kano, Nigeria.

Washington, H. G. (1984). Diversity, Biotic and similarity indices. A review with special relevance to aquatic ecosystems. Water Research, 18(6), pp $653-694$.

WMO (1988): Manual on Water Quality Monitoring. WMO operational Hydrology Report No. 27, WMO Publication No. 680 World Metereology Organisation.

Wright, J.F., Furse, M.T. and Armitage, P.D. (1993). A technique for evaluating the biological quality of rivers in the UK. European water pollution control. p 15-25.

Zamora-Munoz, C. Sainz-Cantero, C.E. and AlbaTercedou, J. (1995). Are biological indices BMWP and ASPT significant regarding water quality, seasonally dependent? Water Res. Vol.29 pp 285-290 